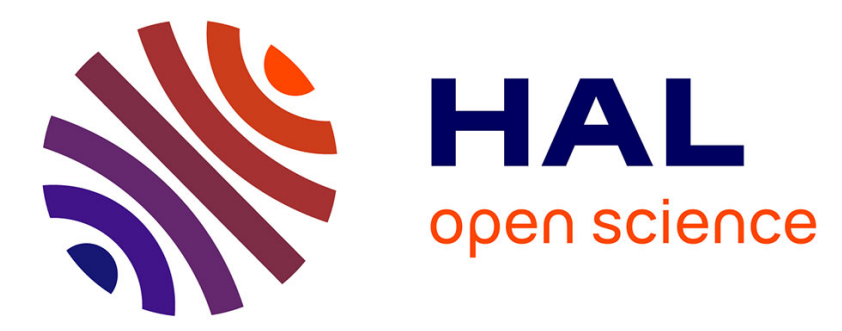

\title{
Does accessibility to local public employment agencies matter? Answers from a French quasi- experiment
}

Matthieu Bunel, Élisabeth Tovar

\section{To cite this version:}

Matthieu Bunel, Élisabeth Tovar. Does accessibility to local public employment agencies matter? Answers from a French quasi- experiment. Applied Economics, 2019, 51, pp.2422-2435. 10.1080/00036846.2018.1545079 . hal-02287397

\section{HAL Id: hal-02287397 https://hal.science/hal-02287397}

Submitted on 9 Oct 2019

HAL is a multi-disciplinary open access archive for the deposit and dissemination of scientific research documents, whether they are published or not. The documents may come from teaching and research institutions in France or abroad, or from public or private research centers.
L'archive ouverte pluridisciplinaire HAL, est destinée au dépôt et à la diffusion de documents scientifiques de niveau recherche, publiés ou non, émanant des établissements d'enseignement et de recherche français ou étrangers, des laboratoires publics ou privés. 


\title{
Does accessibility to local public employment agencies matter? Answers from a French quasi-experiment
}

\author{
Mathieu Bunel ${ }^{\mathrm{a}}$ and Elisabeth Tovar $^{\mathrm{b}}$ \\ aUniversité de la Nouvelle-Calédonie and TEPP Campus Nouville, Nouméa, Nouvelle-Calédonie; buniversité Paris Nanterre and Economic \\ 200, avenue de la République, Cedex Nanterre, France
}

\begin{abstract}
We question whether accessibility to local public employment agencies impacts exits from unemployment. We deal with the potential endogeneity of the residential location of jobseekers by using the unanticipated creation of a new agency in the French region of Lyon as a quasinatural experiment. We use exhaustive and geo-located individual data on jobseekers and local public employment agencies. Contrary to past evidence based on aggregated data, we find no evidence that jobseekers with improved accessibility to the local public employment services experience an improvement of their probability of exiting unemployment. We however find evidence of transitory organizational effects. These findings strongly question the costly strategy of a fine distribution of local public employment agencies across the territory while suggesting that institutional issues are key.
\end{abstract}

\section{KEYWORDS}

Accessibility to public employment services; quasiexperiment; unemployment; difference-in-difference

JEL CLASSIFICATION E24; J68; R53
An extensive literature shows that active labour market public policies have mostly positive effects on exits from unemployment (Card, Kluve, and Weber 2015; Fontaine and Le Barbanchon 2012). However, these policies are expensive. In France, active labour market policies are implemented by 45,000 caseworkers who monitor from 120 to 160 jobseekers each, for a cost estimated between 1,000 to 1,500 euros by jobseeker. A network of 951 local public employment agencies ('agencies' throughout the paper) guarantees that $80 \%$ of jobseekers live less than 30 minutes away from the agency where they are enrolled. Maintaining such a dense network ${ }^{1}$ costs, in rent only, 264 million euros each year (Cour des Comptes 2015) and is also a source of deleterious organizational effects, hampering, for example, the specialization of caseworkers. This is particularly the case in France, where $25.3 \%$ of the agencies have 15 or fewer caseworkers and $71.0 \%$ have 25 or fewer caseworkers.

As a result, recent papers question the causes of the heterogeneous efficiency of the intermediation service provided by agencies, whether in terms of congestion effects, of the marginal efficiency of caseworkers and caseworker strategies, of social proximity between the caseworkers and the jobseekers or of the managerial governance of agencies (Hill, 2006; Behncke, Frölich, and Lechner 2010a, 2010b; Lagerstöm, 2011; Suárez Cano et al. 2015; Launoy and Wälde 2016). In parallel, a growing number of papers focus on network and accessibility issues and find some evidence of adverse effects on unemployment of the geographical distance between jobseekers and agencies, which suggests a new type of suboptimal friction in the job matching process and a new source of spatial mismatch (Gobillon, Selod, and Zenou 2007; Wathen and Allard 2014; Suárez Cano, Mayor Fernández, and Cueto Iglesias 2012a, 2012b).

This paper is a contribution to this second trend of the literature, and tackles several methodological issues that complicate the assessment of an agency accessibility effect on unemployment. The most relevant empirical strategy would be to use individual, geo-located panel data on jobseekers and use GIS techniques to study the effect of

\footnotetext{
${ }^{1}$ The French local public agency network has 951 agencies for a population of 66.3 million and 2.9 million jobseekers; by comparison, the German network has only 621 local public employment agencies for a population of 81 million and 2.8 million jobseekers. In 2009 , $80 \%$ of jobseekers could reach their agency in under 30 minutes, versus $96.4 \%$ in 2012. Comparatively, the average commuting time was 72 minutes for students and employed workers.
} 
intertemporal variations of jobseeker/agency distances on individual unemployment durations. However, individual databases on jobseekers are seldom exhaustive and even less frequently geolocated at a sufficiently fine level for the purpose at hand. Further, there are few intertemporal variations of the distance factor since the networks of agencies is very stable, with few agency relocations. A last methodological difficulty is that the distance factor is not exogenous, since agencies tend to be located in high unemployment zones and it is not possible to discard that, conversely, workers take accessibility to local public employment services into account in their residential location decisions.

As a result most pioneer studies on the accessibility factor, which find a negative effect of distance to agencies on employment (Suárez Cano et al., 2012), do not use individual data but work on data aggregated at the district level, with potential aggregation bias because of modifiable area unit problems ${ }^{2}$ : it is not possible to discard that heterogeneous correlations between aggregated district unemployment durations and distance to agencies do not reflect individual effects but district characteristics (rurality, urbanization patterns, sectorial specialization).

In this paper, we circumvent these methodological problems by 1) taking advantage of a natural quasi- experiment produced by the unanticipated creation of a new local public employment agency in the French region of Lyon, 2) using exhaustive individual geo-located data on jobseekers that allow us to compute individual unemployment durations for a period of 6 years (between 2006 to 2012) controlling by individual characteristics and 3) using GIS techniques to compute individual commuting distances to the local agency where the jobseekers are enrolled.

We show that distance to agencies is not a significant predictor of unemployment durations neither for gross exit or durable exit for unemployment. But we find some transitory evidence of the impact of reorganisation of the agency on jobseeker's employment prospect. These findings strongly question the costly strategy of a fine distribution of local public employment agencies across the territory while suggesting that organization issues are key.
The paper is organized as follows: in Section 2, we discuss the literature. In Section 3, we present the data used and detail our econometric difference-in-difference strategy. In Section 4, we present the results and discuss our findings. Section 5 concludes on public policy issues and further research.

\section{Efficient and accessible public employment agencies}

Many recent papers examine the determinants of the heterogeneous intermediation service provided by public employment agencies (Rosholm 2014): some focus on institutional effects, while others investigate accessibility issues to the network of local public employment agencies.

\section{Institutional effects}

A first strand of the literature on institutional effects focuses on the quantitative dimension of the job matching intermediation provided by local public employment agencies efficiency.

On caseworker efficiency, Lechner and Smith (2007) find, on the Swiss context, that when efficiency is measured by unemployment rates one year after the enrolment in an active labour market program, caseworkers do not seem to add much value in their role of allocators to the services provided by the public placement agencies: they do about as well at this task as random assignment with existing service proportions. By contrast, Lagerstöm (2011) shows, relying on Swedish data, that caseworkers have an important role in the jobseekers' employment rates and future earnings when controlling for the jobseekers' characteristics. Using Danish data on the timing of the meetings between caseworkers and jobseekers, Bech (2015) also finds that from 2 to 7 percent of the variation of the unemployed workers' future labour market outcome can be explained by the variation in the assigned caseworker's performance.

Other recent papers investigate congestion through caseload effects (i.e. number of jobseekers per caseworker). On Dutch data, Koning (2009)

\footnotetext{
${ }^{2}$ For a review of the MAUP problem, see Dusek (2004).
} 
finds is that each additional marginal caseworker significantly increases the unemployment outflow rates for short-term jobseekers (although no effects are found on long-term jobseekers), reduce the inflow rate into social assistance protocols and increases the number of registered vacancies by agency. Although these effects are modest in absolute terms, he concludes that raising the number of caseworkers is cost-effective, and that extra costs are compensated by the resulting reduction in assistance benefits expenses. Similarly, taking advantage of a natural experiment, Hainmueller et al. (2011) find that the caseload reduction of 14 pilot German local employment offices led to a significant decrease of the average local duration of unemployment spells, a decrease on local unemployment rates and increase in local reemployment rates. They also conclude on the costeffectiveness of hiring more caseworkers, the added cost being offset by the savings from decreased benefit expenditures. Interestingly, they also consider potential negative side effects such as spill-over into neighbouring regions. This may occur, in a regional labour market with a limited number of vacancies, if the caseworkers of the pilot agencies fill vacancies in neighbouring regions at the expense of jobseekers from these neighbouring areas. They find no significant local negative spill-overs; on the contrary, their results suggest positive spill-overs that may come from the fact that since all offices share a common vacancy database, neighbouring employment offices benefited from the additional vacancies registered by caseworkers in the pilot offices.

A second strand of the literature investigates more qualitative aspects of the institutional dimension of job matching intermediation in local public employment agencies.

Lagerstrom (2011) also provides evidence of the importance of the working strategies of caseworkers, and shows that the caseworker who send their clients to class room training services ${ }^{3}$ are less successful than those that do not assign to programs but choose instead to support and help their clients in their search for employment. This result provides insight on the caseload discussion: because a heavy caseload means less time available for face-to-face monitoring and counselling, caseworkers could be tempted to enrol their jobseekers in time-saving, but less effective, collective programs.

In the same spirit, Behncke, Frölich, and Lechner (2010a) study the effect of caseworkers' cooperativeness with her jobseekers on their employment outcomes. Because caseworkers both counsel and monitor the jobseekers, they may develop conflicting strategies where they may either try and satisfy the jobseekers' demands or assign them to jobs and labour market programs on the sole grounds of efficiency, regardless of their consent. They show that caseworkers who place less emphasis on a co-operative and harmonic relationship with their clients (i.e. who believe that they should assign their clients to jobs and programs without necessarily taking their preferences into account) increase their chances of employment in the short and medium term. They also show that there are no adverse consequences on the stability of the newfound jobs. Finally, they show that this positive effect is not mediated by actual sanctions or active labour market programs but seems to transit through changes in behaviour and trust between caseworkers and jobseekers. Interestingly, they find that the caseworkers' caseload (number of clients that caseworkers report to have counselled on average) does not affect the results.

In a companion paper, Behncke, Frölich, and Lechner (2010b) focus on the social proximity between caseworkers and jobseekers. They find significant positive effects of similar social identity (defined by education, gender, age and nationality) between caseworkers and jobseekers on the employment prospects of jobseekers, controlling by tenure, previous experience in a municipal employment office, previous experience in a private placement agency, own experience of unemployment, participation in special caseworker training and caseload.

Launoy and Wälde (2016) show that organizing the work of an agency in a more efficient way has a much better result for unemployment than

\footnotetext{
${ }^{3}$ This result stemming from experimental data is consistent with the meta-analysis papers presented above, where training policies were shown to be less effective than the 'services and sanctions' active labour market policies.
} 
creating pecuniary incentives through unemployment assistance benefits.

\section{Accessibility effects}

Many recent papers place an emphasis on the spatial dimension of public intermediation in the labour market as an important factor in the efficiency of the job/worker matching process.

This concern is typically found in recent papers that focus on the evaluation of active labour market policies, where geographical differences are used to introduce variability in the labour market policy frameworks (Frölich and Lechner 2010; Altavilla and Caroleo 2013; Ferracci, Jolivet, and van Den Berg 2014).

Other papers directly question the potentially detrimental effects of the geographical distance between agencies and their recipients.

For local public employment agencies, JoassartMarcelli and Giordano (2006) find a significant negative link between accessibility to agencies and unemployment. At the census tract level, they show accessibility differentials by race/ethnicity, age, and location. They also find that access to Californian One-Stop Career Centres reduces aggregated unemployment, with larger effects for groups that experience limited mobility due to gender or race, such as black and female jobseekers.

Suárez-Cano et al. (2012a, 2012b, 2015) study, in the Spanish context, the effect of the accessibility of local public employment offices on local unemployment rates varies according to the distribution of three different types of municipalities: large urban, small urban and non-urban. They also find that, at the municipal level, accessibility to employment offices significantly affects jobseekers' labour market outcomes and that this effect is particularly important in non-urban areas where employment opportunities are limited.

This converging empirical evidence has direct public policy implications, suggesting that a denser spatial network of agencies would effectively decrease unemployment, especially in rural areas.

In France, this concern underlies the ongoing debate on reform of Pôle Emploi, the public employment service. Pôle Emploi was created in December 2008 by the merging of the institutions formerly in charge of jobseeker monitoring and control (ANPE) and of the distribution of unemployment benefits (ASSEDIC). Its creation, coincidental with the 2008 financial crisis, led to institutional dysfunction, without any real managerial reorganization of the new Pôle Emploi agencies. There was also no redefinition of the local public employment agency network. The French Audit Court ${ }^{4}$ criticizes the relative dispersion of caseworkers, their reduced specialization and the unnecessary duplication of tasks across agencies (e.g. human resources, benefit distribution, call centres). In 2014, almost a quarter (24\%) of the Pôle Emploi workforce was not actively devoted to the counselling and monitoring of jobseekers. Moreover, the actual monitoring of jobseekers took up a maximum of only $37 \%$ of actual caseworkers' time, and the locating of vacancies up to $7 \%$ of their time. In terms of cost, the Court reports that the space occupied by agencies showed a 15.9\% increase between 2009 and 2013; with $85 \%$ of this space being rented to private landlords, the yearly rent of the agencies increased by $21.6 \%$ between 2011 and 2014, reaching 264 million euros in 2014. Consequently, the Court has mandated a reduction of the number of agencies in the years to come; in a Rawlsian fashion, this measure is to be offset by specific mechanisms for jobseekers who live far away from agencies (Cour des Comptes 2015).

The paper's objective is to provide evidence on whether an improvement of agency accessibility is likely to have a positive impact or not on durable exits from unemployment.

\section{Data and empirical strategy}

To do so, we propose an empirical strategy designed to bypass long-lasting methodological difficulties caused by the ecological fallacy problem and spatial endogeneity issues. First, use a previously unexploited exhaustive, individual and geo-located dataset on jobseekers that was exceptionally made available to us by the French Rhône-Alpes region. Second, we take advantage of

${ }^{4}$ Cour des Comptes, who conducts financial and legislative audits of French public institutions. 
a natural quasi-experiment that allows us, using a difference-in-difference model, to estimate whether experiencing a significant improvement of their accessibility to the agency where they are enrolled has a significant effect on durable exits from unemployment.

\section{The data}

To collect individual information on the jobseekers, we use the longitudinal Pôle Emploi dataset, which provides an exhaustive record of all unemployed jobseekers (18-65 years old) during a long period of time (8 years). We focus on the June, 2006 to April, 2012 period to stay within the parameters of a single active labour market policy framework: as noted by Fontaine and Le Barbanchon (2012), 2005 was a turning point in the generalization of active labour market policies in France, with another drastic modification of the monitoring and control of jobseekers taking place in 2013.This individual, exhaustive dataset provides the following variables: unemployment duration, gender, nationality, number of children, marital status, educational level, age, name and location of their agency and residential location of jobseekers (at the municipal level ${ }^{5}$ ).

This information allows the computing of unemployment recurrence for the 2004 to 2012 period and the control for jobseeker residential moves that could otherwise lead to underestimation of unemployment duration.

To take into account unemployment recurrence, we first calculate the total duration of unemployment spells during the last 2 and a half years before each new entry of an unemployed jobseeker in the agency register. To measure the durability of the exits from unemployment, we also compute the gap between a jobseeker's last unemployment spell and her actual one. To compute these two elements, we use the exit of a jobseeker from the individual Pôle Emploi dataset, where the motive for the exit is not noted. Global surveys establish that the majority of exits from the Pôle Emploi databases are 'true' exits from unemployment through job matches (46.7\% of the exits in March 2011) or the resumption of studies (9.9\% of the exits) (Bernardi and Poujouly 2011). Jobseekers involuntarily exit the Pôle Emploi database because of administrative mishaps (24.8\% of the exits).

Because we use an exhaustive dataset, we can track the immediate re-entry of the jobseekers in the database and exclude these 'false' exits from unemployment from our variables of interest (unemployment duration and durability of exits from unemployment). Jobseekers also transition to inactivity $(0.9 \%$ of the exits) or temporarily suspend their job search for maternity, military, holidays or medical reasons (8.2\% of all exits).

In these cases, the nature of our database does not allow us to track and exclude these exits from the computation of our variables of interest; however, the impact of this shortcoming is lessened by the fact that there is virtually no link between these motives for exit and jobseeker/agency distance. In contrast, the remaining motives are more problematic for us because they can, at least partially, be caused by the demotivation of jobseekers, which in turn may be affected by a too-great distance to the jobseeker's agency. A mitigating factor is that these exits are few $(9.4 \%$ of all exits in March 2011), so that the overall impact on our estimations is bound to be weak.

Another issue is the added value of the public intermediation service on the job search process: in 2011 , only $14 \%$ of the job matches were directly organized by Pôle Emploi (Bernardi 2013). Moreover, 28\% of the new job matches were created through personal or professional relations and $22 \%$ through unsolicited applications, which underlines the increasing role of informal and decentralized search processes (such as Internedbased job searches, Kuhn and Mansour 2014) for which no datasets exist. However, the mission of the public intermediation goes beyond the mere matching of jobs and workers: since the implementation of active labour market policies, it also focuses on helping jobseekers implement efficient and diversified search strategies, which has indirect positive effects on jobseekers' employment prospects, as shown by the converging empirical evidence on the evaluation of active labour market policies. Caseworkers counsel jobseekers on 
writing resumes, using the Internet in their job search, devising an effective spontaneous application strategy, identifying job opportunities and activating their personal and professional networks.

Second, measure the geographical accessibility of local public employment agencies using the Odomatrix@dataset (Hilal 2010). Due to confidentiality issues, the exact address of each jobseeker was not available to us. As is common in the literature, we assign each jobseeker's residential location at his municipality's centroid. Accessibility of local public employment services is therefore computed, for each jobseeker, as the as the duration (in minutes) of the trip (by car) between this centroid and the exact address of the agency where he is enrolled. We use time distances rather than pure Euclidian distances because it takes into account congestion and actual road networks.

\section{Zoning modifications as a quasi-natural experiment}

Our study area (called 'Belleville zone' throughout this paper) is located in the suburban Northern part of the Greater Lyon area, France's thirdlargest city in size. It is composed of 399 municipalities located in six agency catchment areas: Roanne, Riorges, Tarare, Belleville, Villefranche, Bourg-en-Bresse and Trevoux.

This area is interesting because of a modification of the spatial distribution of the agencies that took place in December 2008, when Pôle Emploi was created. Before December 31st, 2008, all the jobseekers who lived in the 104 municipalities situated in the Belleville zone were enrolled in the agency of Villefranche-sur-Saône. In January 1st, 2009, a new agency opened in Belleville (Figure 2), its catchment area comprising the 43 northern municipalities of the zone. The catchment area of the Villefranche agency ${ }^{6}$ was reduced to the 61 southern municipalities of its prior catchment area. The creation of the Belleville agency created a variation in the geographical distance between jobseekers and the placement agencies in the area, creating a quasi-natural experiment. Controlling for all individual jobseeker characteristics in the use of exhaustive individual datasets (see above), it is therefore possible to check whether 'pure' spatial effects affect jobseekers' unemployment prospects.

Additionally, this area is comprised of rural and semi-rural municipalities, which echoes the literature. In France, evidence of job/workers spatial mismatch is more convincing for rural areas (Détang-Dessendre and Gaigné, 2009). Moreover, Suárez-Cano et al. underline that detrimental effect of poor accessibility to agencies are more important for rural areas (Suárez-Cano et al., 2012a).

\section{Identification strategy (2) difference-in-difference model}

To account for endogeneity in the location of agencies and jobseekers, we take advantage on the quasi-experiment generated by the unanticipated creation of a new agency in the municipality of Belleville and use a difference in difference econometric strategy that considers three pairs of treated and control groups.

\section{Treated and control groups}

\section{- Belleville jobseekers vs. outsiders}

Treated Group 1 (in green and in red in Figure 1) is the group of jobseekers who 1) live in the municipalities located in the catchment area of the new Belleville agency, 2) were formerly enrolled in the Villefranche agency and 3) benefited, with the creation of the Belleville agency, from a significant reduction of the travel time between their home and their Pôle Emploi agency (on average, almost a $50 \%$ decrease, dropping from 25 to 12 minutes for a one-way trip (Figure 2).

Control Group 1 (in blue in Figure 2) is a group of jobseekers who were not affected by the creation of the new Belleville agency, i.e. who live in the municipalities that are located 1) inside the catchment areas of nearby agencies, 2) not including Villefranche and Trevoux, 3) outside the Belleville Employment Zone.

\footnotetext{
${ }^{6}$ The Villefranche agency also moved in 2013; however, this change was implemented after our period of investigation. Furthermore, it remained within such a small perimeter (less than $500 \mathrm{~m}$ from its initial location) that we suppose that this move is trivial and will have no impact whatsoever in the future.
} 


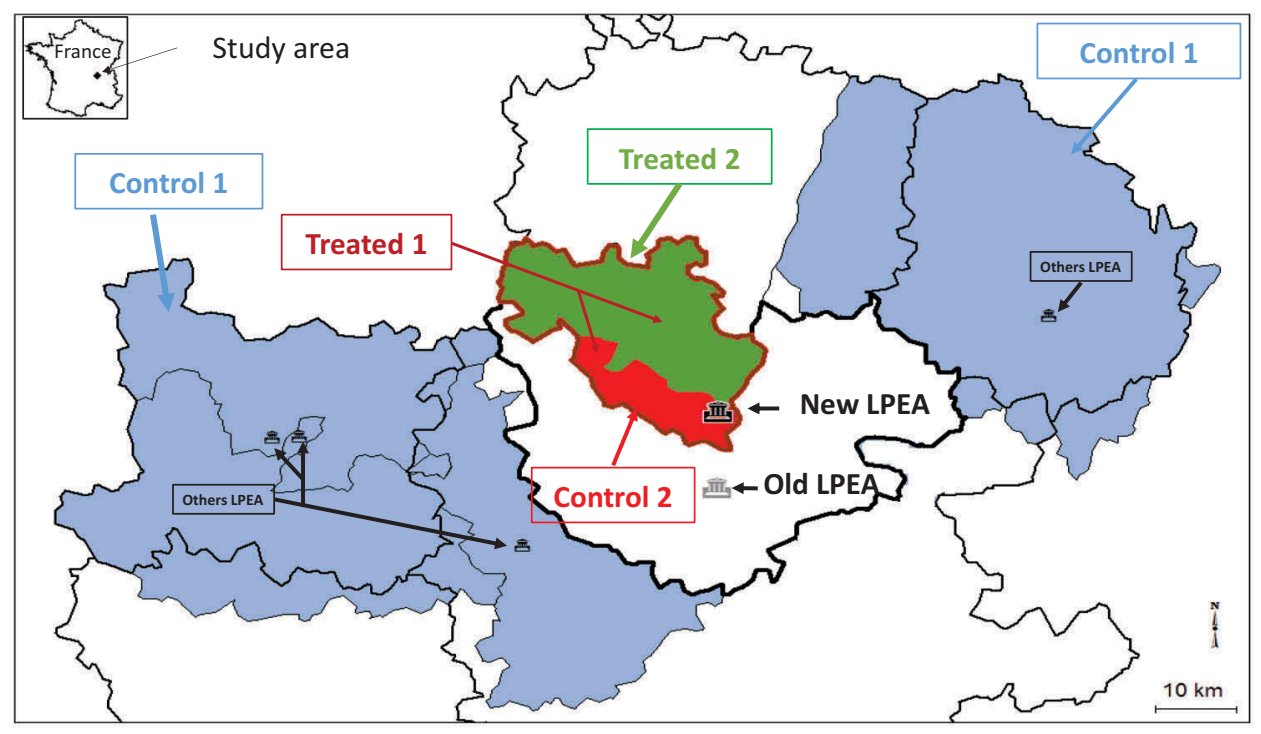

Figure 1. Control and treated groups.

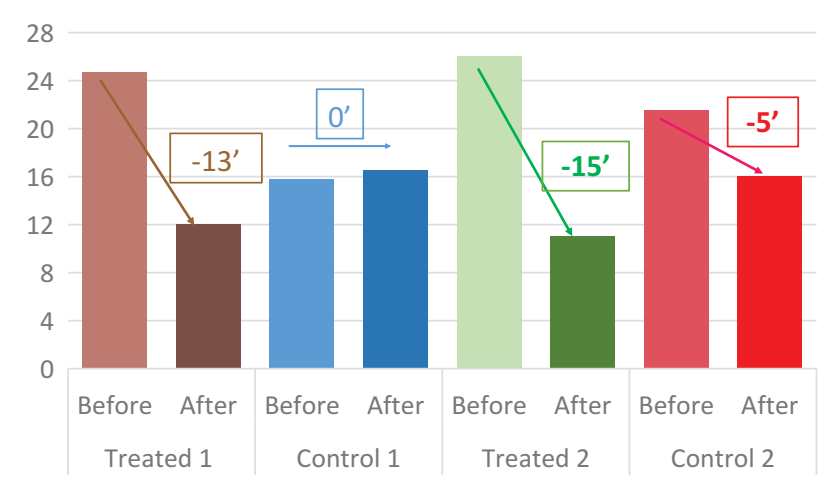

Figure 2. Time travel to the agency before and after the Belleville creation.

Source: Odomatrix and FHS-Pôle Emploi, first spell per jobseeker

In Figure 2, we can observe that the travel times to these jobseekers' agencies were not significantly altered after the Belleville creation. First, the Roanne, Riorges, Tarare and Bourg-en-Bresse agencies were chosen because they are geographically close ${ }^{7}$ to the Belleville-Villefranche areas and because, being in rural or semi-rural areas, they share similar socio-economic characteristics.

Second, the jobseekers enrolled in the Villefranche and Trevoux agency are excluded because they may be directly affected by the creation of the Belleville agency in different opposite ways. On the one hand, the reduction of the catchment area of the Villefranche agency contributes to a reduction in the caseloads of Villefranche caseworkers, which may lead to greater efficiency and better outcomes for Villefranche jobseekers. On the other hand, the creation of a specific agency for Belleville jobseekers could lead to better placement prospects for them, i.e. increased competition for Villefranche jobseekers living in the same Employment Zone.

Third, as noted by Rubin (1977), to identify causal effect, it is important to be in a situation where we do not observe interactions between the treated and control groups. The well-known stable unit treatment value assumption (SUTVA) assumes that the treatment status of any unit does not affect the potential outcomes of the other units. To minimize the potential interactions between the treated and the control groups, we exclude from Control Group 1 all the jobseekers who live in the same Employment Zone as the Belleville treated group. Defined using Census data $^{8}$ by the French National Statistics Institute (INSEE), an employment zone is a homogeneous labour market zone, i.e. an area within which most of the labour force lives and works and in which firms can find the main part of the labour force necessary to occupy the offered jobs. Restricting the control group to jobseekers who live outside the employment zone of the treated group should

\footnotetext{
${ }^{7}$ Other nearby areas north of the zone could also be included in the control group but are located outside the Rhône region, i.e. outside the perimeter of our datasets.

${ }^{8}$ The zoning used in the paper is based on the flows of movement from residence to work of active persons observed in the 2006 Census.
} 
limit the interactions between the two groups. We also exclude the jobseekers who live in the catchment area of the Trevoux agency because most of them are also located in the Belleville employment zone.

- Distance-affected vs. non-affected Belleville jobseekers

The second treated/control group pair is defined to disentangle institutional and distance effects. Treated Group 2 is defined as the jobseekers who, within the Belleville area, benefited from a substantial reduction of their travel time to their agency (more than 14 minutes on average, see Figure 2) (in green in Figure 1): they were affected by both a distance and an institutional change.

Control Group 2 group is formed by jobseekers who were affected by the institutional change but who did not benefit from proximity effects after the creation of the Belleville agency, i.e. jobseekers who live near both their former Villefranche and their new Belleville agencies, so that they gained less than 10 minutes ( 5 minutes on average, see Figure 2) in their travel time to their agency (in red in Figure 1).

- Un-activated Belleville jobseekers vs outsiders

The last treated/control group is designed to assess, very classically, an 'activation effect' of labour market public policies. Treated Group 3is constituted by the short-term jobseekers who, while living in the Belleville catchment area, were not affected by the creation of the new agency: because their unemployment spell lasted less than 4 months, they were not yet enrolled in any kind of active labour market public policies. Control Group 3 is composed by the short-term jobseekers who live, exactly as Control Group 1, outside the municipalities of the Villefranche-Belleville employment zone. Controlling for individual characteristics, in line with the vast literature that establishes the positive role of public placement service on the unemployment prospects of jobseekers, we expect to find that the outcomes of Treated and Control Group 3 are not significantly different.

\section{Parametric estimation}

A first way of measuring the effect of agency accessibility on unemployment is to use a parametric estimation strategy where the causal effect is represented by the coefficient of the interaction term $\gamma_{3}$ in a regression.

$$
Y_{i t}=\beta^{\prime} X_{i}+{ }_{1} T_{t}+{ }_{2} \mathrm{~d}_{i}+\gamma_{3} \mathrm{~d}_{i} \times \mathrm{T}_{\mathrm{t}}+u_{i t}
$$

Where

- $\mathrm{T}_{\mathrm{t}}$ is a dummy variable equals to 1 for periods after the creation of the Belleville agency takes place and 0 otherwise.

- $\mathrm{d}_{i}$ is a dummy variable equals to 1 if unemployed is localised in the Belleville agency area and 0 otherwise.

- $X$, a set of individual explanatory variables (age, gender, diploma, years of professional experience, trimester of entry in unemployment, duration of unemployment spells in the last 30 months and a constant);

Note that in a logit model, the marginal effect associated with the treatment in the period in which the treatment is implemented $\left(\mathrm{d}_{i} \times \mathrm{T}_{\mathrm{i}}\right)$ is obtained by using

$$
\begin{aligned}
\frac{\partial p_{i}}{\partial \mathrm{d}_{i} \times \mathrm{T}_{\mathrm{i}}} & =\frac{\Delta p_{i}}{\Delta \mathrm{d}_{i} \times \mathrm{T}_{\mathrm{i}}} \\
& =\left(\beta^{\prime} X_{i}+\gamma_{3}\right)-\left(\beta^{\prime} X_{i}\right)
\end{aligned}
$$

where $\Delta($.$) is the differential operator and (.) the$ logistic distribution function. Additionally, to account for learning effects by caseworkers in the new agency, we introduce three dummy variables for the years 2009, 2010 and 2011.

\section{Non-parametric estimation}

In the difference-in-difference method, we assume that the treated and the control groups are subject to the same aggregated labour market trends. This methodology gives the effect of the treatment on the treated controlling for the individual-specific effect fixed over time and time-specific effect common to all agents. However, our data are not a true panel.

To address this issue, we implemented the matching method with the difference-in-difference method proposed by Blundell and Costa Dias (2000). In this framework, the non-random treatment assignment 
bias is reduced by balancing the treated and the control groups on the observed covariates.

The non-parametric method of propensity matching allows selecting a control group on the basis of a single score. To find a comparably treated group before the introduction of the new agency, we use

$$
\begin{aligned}
\gamma_{4}= & \sum_{i \in d_{1}}\left[Y_{i T_{1}}^{d_{1}}-\sum_{t \in T_{0}} w_{i t}^{d_{1}} Y_{t}^{d_{1}}\right) \\
& \left.\left.-\sum_{t \in T_{1}} w_{i t}^{d_{0}} Y_{\mathrm{t}}^{d_{0}}-\sum_{t \in T_{0}} w_{i t}^{d_{0}} Y_{\mathrm{t}}^{d_{0}}\right)\right]
\end{aligned}
$$

Where $w_{i T}^{G}$ represents the weights attributed to individual $i$ in group $\mathrm{G}$ (where $\mathrm{G}=d_{0}$ or $d_{1}$ ) in period of time $\mathrm{t}$ (where $\mathrm{t}=T_{0}$ or $T_{1}$ ), where $d_{1}$ is a binary variable equal to 1 if the jobseeker lives in a community in the agency catchment area of Belleville and 0 otherwise and $\mathrm{X}$ is a vector of covariates. The selection of the control group based on $P_{d X}$ and $P_{T X}$ is possible if given those probabilities (or scores), exposure to the treatment is independent of the covariates $(\mathrm{X}){ }^{9}$

The average treatment on the treated is obtained by using command psmatch 2 in Stata $\odot$ software (Becker and Ichino 2002). The matching is restricted to the area of common support and is based on the kernel matching procedure (for each treated, all the controls are considered with a weight inversely proportional to the distance between the propensity score of treated individuals and control individuals). To take into account the discrete nature of the outcome variable, the impact of the treatment obtained with Stata@ is modified using the method proposed by Blundell et al. (2004).

\section{Results}

\section{Accessibility differentials to agencies}

In our study area, we find that, on average, municipalities are located just under 30 minutes from their agencies (Table 1). Note that this result is measured at the municipality level, without accounting for population density disparities between municipalities. In contrast, individual travel times are, on average, inferior (17.8 minutes for a one-way trip),
Table 1. Accessibility to local job employment agencies (minutes).

\begin{tabular}{lrr}
\hline Municipality profile (2012 data) & Mean & Std \\
\hline Metropolitan status & 38.8 & \\
Rural & 29.0 & 10.4 \\
Suburban & 21.0 & 11.8 \\
Urban & & \\
Income & 28.6 & 13.2 \\
Rich: top 10 municipal median income & 38.4 & 6.5 \\
Poor: bottom 10 municipal median income & & \\
Education & 30.9 & 9.5 \\
High: top 10 with the highest \% with a college degree & \\
Low: top 10 with the highest \% with a diploma inferior & 34.7 & 9.2 \\
$\quad$ to the Bac* & & \\
Unemployment & 24.1 & 17.3 \\
High: top 10 unemployment rate & 35.2 & 9.3 \\
Low: bottom 10 unemployment rates & & \\
Workforce & 36.4 & 8.3 \\
Blue-collar: top 10 proportion of blue collar workers & 35.7 & 7.0 \\
White-collar: top 10 proportion of white collar workers & 29.1 & 11.2 \\
All agencies & & \\
\hline
\end{tabular}

Sources: Odomatrix, INSEE Census. $\left(^{*}\right)$ The Bac (Baccalauréat) is the French equivalent of the A-Levels

which highlights the potential bias that might arise when working with aggregated data.

Consistent with past empirical evidence (Allard and Danziger 2003; Joassart-Marcelli and Giordano 2006; Suárez Cano, Mayor Fernández, and Cueto Iglesias 2012a, 2012b; Suárez Cano et al. 2015), we find notable average differentials in accessibility to agencies between municipalities: rich, educated and white collar municipalities are, on average, closer to agencies than poor, uneducated and blue collar municipalities. Additionally, supporting Suárez Cano, Mayor Fernández, and Cueto Iglesias (2012a), we find that, on average, travelling to one's agency takes almost twice the time for jobseekers who live in rural municipalities as for jobseekers who live in urban ones (38.8 minutes versus 21.0 minutes).

In particular, the municipalities with high unemployment also tend to be, on average, closer to agencies than municipalities with low unemployment rates (35.2 versus 24.1 minutes); this result hints that the spatial distribution of agencies is not exogenous but rather deliberately targets high-unemployment urban zones.

\section{Difference-in-difference results}

Using to the quasi-experimental framework created by the creation of the Belleville agency, we are able to test our working hypothesis of no

\footnotetext{
${ }^{9}$ See companion paper for the presentation of matching propensity scores of the treated versus control groups and before versus after the creation of the agency (Bunel and Tovar, 2015).
} 
jobseeker/agency distance effects on the probability of exiting unemployment.

First, let's focus on results of the difference-indifference and matching estimations between Treated and Control groups 1. For the years 2010 and 2011, we find no significant impact of the creation of the new agency on the employment outcomes of jobseekers (see Table 2a): there are no significant differences between the unemployment exits of the Belleville area jobseekers and the jobseekers of Control Group 1, who were not affected by the creation of the new agency. This result is robust to the estimation method (difference-in-difference vs. matching) and to the definition of unemployment exits (gross and durable short-term unemployment exits).

However, this result does not hold for either gross or durable exits from unemployment if we also take into account the year 2009, i.e. the year where the Belleville agency was created. For the year 2009 and the 2009-2011 period as a whole, distance to agencies has a significant negative impact on job matching outcomes. Furthermore, marginal effects are quite high: in 2009, the marginal treatment effect on the treated ranges from -0.118 to -0.290 depending on the definition of employment outcomes and the method of estimation. They mean that in 2009, the probability of exiting unemployment of jobseekers belonging to the new Belleville

Table 2. Difference-in-difference results.

\begin{tabular}{|c|c|c|c|c|c|c|c|c|c|}
\hline \multicolumn{6}{|c|}{ Parametric } & \multicolumn{4}{|c|}{ Matching } \\
\hline \multicolumn{2}{|c|}{ All years } & \multicolumn{2}{|r|}{2009} & \multicolumn{2}{|c|}{ 2010-11 } & \multirow{2}{*}{$\begin{array}{r}\text { All years } \\
\text { Marginal treatment } \\
\text { effect on treated }\end{array}$} & \multirow{2}{*}{\multicolumn{2}{|c|}{$\begin{array}{l}2009 \\
\text { inal treatment } \\
\text { fect on treated }\end{array}$}} & \multirow{2}{*}{$\begin{array}{r}\text { 2010-11 } \\
\text { Marginal treatment } \\
\text { effect on treated }\end{array}$} \\
\hline Coef (std) & Marg. effect & Coef (std) & Marginal effect & Coef (std) $\quad M$ & Marginal effect & & & & \\
\hline \multicolumn{10}{|c|}{$\begin{array}{l}\text { a. Belleville jobseekers vs. outsiders (Treated } 1 \text { vs. Control 1) } \\
\text { Gross exits }\end{array}$} \\
\hline 6 months & $\begin{array}{l}-0.472^{* * *} \\
(0.098)\end{array}$ & -0.071 & $\begin{array}{l}-1.934^{* * *} \\
(0.201)\end{array}$ & -0.290 & $\begin{array}{l}-0.107 \\
(0.104)\end{array}$ & -0.017 & $\begin{array}{l}-0.068^{* * *} \\
(0.014)\end{array}$ & $\begin{array}{l}-0.118^{* * *} \\
(0.042)\end{array}$ & $\begin{array}{r}-0.007 \\
(0.051)\end{array}$ \\
\hline 12 months & $\begin{array}{l}-0.404^{* * *} \\
(0.082)\end{array}$ & -0.095 & $\begin{array}{l}-1.081^{* * *} \\
(0.107)\end{array}$ & -0.252 & $\begin{array}{c}-0.082 \\
(0.09)\end{array}$ & -0.019 & $\begin{array}{l}-0.105^{* * *} \\
(0.020)\end{array}$ & $\begin{array}{l}-0.277^{* * *} \\
(0.090)\end{array}$ & $\begin{array}{c}-0.001 \\
(0.091)\end{array}$ \\
\hline \multicolumn{10}{|l|}{ Durable exits } \\
\hline 6 months & $\begin{array}{l}-0.449^{* * *} \\
(0.153)\end{array}$ & -0.029 & $\begin{array}{l}-1.487^{* * *} \\
(0.229)\end{array}$ & -0162 & $\begin{array}{c}-0.113 \\
(0.160)\end{array}$ & 0.002 & $\begin{array}{l}-0.033 \\
(0.074)\end{array}$ & $\begin{array}{l}-0.179^{* * *} \\
(0.056)\end{array}$ & $\begin{array}{c}-0.001 \\
(0.021)\end{array}$ \\
\hline 12 months & $\begin{array}{c}-0.124 \\
(0.083)\end{array}$ & -0.027 & $\begin{array}{l}-0.684^{* * *} \\
(0.115)\end{array}$ & -0.149 & $\begin{array}{l}0.100 \\
(0.09)\end{array}$ & 0.022 & $\begin{array}{c}-0.038 \\
(0.024)\end{array}$ & $\begin{array}{l}-0.279^{* * *} \\
(0.089)\end{array}$ & $\begin{array}{c}-0.001 \\
(0.021)\end{array}$ \\
\hline \multicolumn{10}{|c|}{$\begin{array}{l}\text { b. Distance-affected vs. non-affected Belleville jobseekers (Treated } 2 \text { vs. Control 2) } \\
\text { Gross exits }\end{array}$} \\
\hline 6 months & $\begin{array}{l}0.015 \\
(0.206)\end{array}$ & 0.002 & $\begin{array}{c}-0.526 \\
(0.520)\end{array}$ & -0.065 & $\begin{array}{l}0.006 \\
(0.213)\end{array}$ & 0.001 & $\begin{array}{c}0.013 \\
(0.026)\end{array}$ & $\begin{array}{c}-0.022 \\
(0.031)\end{array}$ & $\begin{array}{l}0.021 \\
(0.034)\end{array}$ \\
\hline 12 months & $\begin{array}{l}0.079 \\
(0.172)\end{array}$ & 0.018 & $\begin{array}{l}-0.010 \\
(0.239)\end{array}$ & -0.002 & $\begin{array}{l}0.053 \\
(0.185)\end{array}$ & 0.012 & $\begin{array}{l}0.027 \\
(0.045)\end{array}$ & $\begin{array}{l}0.004 \\
(0.010)\end{array}$ & $\begin{array}{l}0.0150 \\
(0.048)\end{array}$ \\
\hline \multicolumn{10}{|l|}{ Durable exits } \\
\hline 6 months & $\begin{array}{c}-0.114 \\
(0.246)\end{array}$ & -0.011 & $\begin{array}{c}-1.106 \\
(0.767)\end{array}$ & -0.007 & $\begin{array}{c}-0.075 \\
(0.252)\end{array}$ & -0.009 & $\begin{array}{l}0.004 \\
(0.010)\end{array}$ & $\begin{array}{c}-0.024 \\
(0.025)\end{array}$ & $\begin{array}{l}0.014 \\
(0.034)\end{array}$ \\
\hline 12 months & $\begin{array}{c}-0.022 \\
(0.173)\end{array}$ & -0.005 & $\begin{array}{l}-0.246 \\
(0.265)\end{array}$ & -0.047 & $\begin{array}{l}-0.007 \\
(0.184)\end{array}$ & -0.002 & $\begin{array}{c}-0.002 \\
(0.005)\end{array}$ & $\begin{array}{c}-0.022 \\
(0.028)\end{array}$ & $\begin{array}{c}-0.002 \\
(0.009)\end{array}$ \\
\hline \multicolumn{10}{|c|}{$\begin{array}{l}\text { c. Un-activated Belleville jobseekers vs un-activated outsiders (Treated } 3 \text { vs. Control 3) } \\
\text { Gross exits }\end{array}$} \\
\hline 1 month & $\begin{array}{l}0.072 \\
(0.049)\end{array}$ & 0,015 & $\begin{array}{l}0.039 \\
(0.060)\end{array}$ & 0,008 & $\begin{array}{l}0.092 \\
(0.057)\end{array}$ & 0,019 & $\begin{array}{l}0.011 \\
(0.012)\end{array}$ & $\begin{array}{l}0.008 \\
(0.012)\end{array}$ & $\begin{array}{c}0.010 \\
(0.014)\end{array}$ \\
\hline 2 months & $\begin{array}{c}0.045 \\
(0.047)\end{array}$ & 0.010 & $\begin{array}{c}0.000 \\
(0.057)\end{array}$ & 0.000 & $\begin{array}{c}0.081 \\
(0.055)\end{array}$ & 0.018 & $\begin{array}{c}0.006 \\
(0.011)\end{array}$ & $\begin{array}{c}0.001 \\
(0.013)\end{array}$ & $\begin{array}{c}0.010 \\
(0.013)\end{array}$ \\
\hline 3 months & $\begin{array}{c}0.050 \\
(0.060)\end{array}$ & 0.007 & $\begin{array}{c}-0.022 \\
(0.073)\end{array}$ & -0.003 & $\begin{array}{c}0.011 \\
(0.071)\end{array}$ & 0.015 & $\begin{array}{c}0.002 \\
(0.009)\end{array}$ & $\begin{array}{c}-0.005 \\
(0.010)\end{array}$ & $\begin{array}{c}0.007 \\
(0.010)\end{array}$ \\
\hline
\end{tabular}

Interpretation of the table: in 2009, using the parametric estimation strategy, the probability of gross 6-month durable exits from unemployment for jobseekers belonging to the new Belleville agency (Treated Group 1) was $29.0 \%$ lower than the probability off gross 6-month durable exits from unemployment of the jobseekers of Control group 1.

Source: FHS-Pôle Emploi, first spell per individual.

Number of observations: 94,650 .

Covariates: gender, diploma ( 3 levels), age, and time since the last unemployment spell, job experience and quarter of entrance in unemployment, and agency fixed effect.

Gross exits: difference of the effect of distance on the probability of exiting unemployment after having been unemployed for 6 and 12 months.

Durable exits: difference of the effect of distance on the probability of not having been unemployed the 6 and 12 months that followed an exit from unemployment.

*** significant at $1 \%,{ }^{* *}$ at $5 \%,{ }^{*}$ at $10 \%$. Standard errors are given in parenthesis below the estimate. The propensity score matching standard errors are obtained by bootstrap with 200 replications. 
agency was between 11.8 and 29.0 points of percentage lower than the jobseekers of Control group 1.

How can this result be explained? An intuitive answer, in line with seminal papers on the institutional determinants of agency efficiency, is that the initial poor efficiency of the Belleville agency is due to transitory institutional dysfunctions during the agency's start-up period.

To test this explanation, we compare the outcomes of the Treated and Control groups 2, which share the institutional effects of the creation of the new agency but differ in the 'pure' accessibility effect since the agency accessibility of the jobseekers of Control group 2 was not significantly affected after the creation of the new Belleville agency. Whatever the estimation period, the exits from unemployment definition or the estimation methodology, we find no significant evidence of an accessibility effect on the employment outcomes of jobseekers (see Table 2b).

This result of no agency/jobseeker spatial mismatch is in direct contradiction with previous evidence found in the literature. It underlines the importance of using a methodology that tackles potential spatial endogeneity issues.

In addition, our results are consistent for different sub-categories of jobseekers: male vs. female and educated vs. uneducated (no education after A-Levels) jobseekers (see Table $3^{10}$ ): there are

Table 3. Difference-in-difference results by gender and education for 2009 (parametric estimation).

\begin{tabular}{|c|c|c|c|c|c|c|c|}
\hline \multicolumn{4}{|c|}{ Parametric } & \multicolumn{4}{|c|}{ Matching } \\
\hline \multicolumn{2}{|r|}{ Men } & \multicolumn{2}{|r|}{ Women } & \multicolumn{2}{|c|}{ Educated } & \multicolumn{2}{|c|}{ Less educated } \\
\hline Coef (std) & Marginal effect & Coef (std) & Marginal effect & Coef (std) & Marginal effect & Coef (std) & Marginal effec \\
\hline \multirow{2}{*}{\multicolumn{8}{|c|}{$\begin{array}{l}\text { a. Belleville jobseekers vs. outsiders (Treated } 1 \text { vs. Control 1) } \\
\text { Gross exits }\end{array}$}} \\
\hline & & & & & & & \\
\hline 6 months & $\begin{array}{l}-2.029^{* * *} \\
(0.315)\end{array}$ & -0.321 & $\begin{array}{l}-1.963^{* * *} \\
(0.253)\end{array}$ & $\begin{array}{l}-1.842^{* * *} \\
(0.307)\end{array}$ & -0.299 & $\begin{array}{l}-2.090^{* * *} \\
(0.257)\end{array}$ & -0.314 \\
\hline 12 months & $\begin{array}{l}-1.336^{* * *} \\
(0.161)\end{array}$ & -0.307 & $\begin{array}{l}-1.112^{* * *} \\
(0.132)\end{array}$ & $\begin{array}{l}-1.030^{* * *} \\
(0.166)\end{array}$ & -0.235 & $\begin{array}{l}-1.326^{* * *} \\
(0.129)\end{array}$ & -0.312 \\
\hline \multicolumn{8}{|l|}{ Durable exits } \\
\hline 6 months & $\begin{array}{l}-1.429 * * * \\
(0.367)\end{array}$ & -0.156 & $\begin{array}{l}-1.680^{* * *} \\
(0.285)\end{array}$ & $\begin{array}{l}-1.714^{* * *} \\
(0.384)\end{array}$ & -0.210 & $\begin{array}{l}-1.513^{* * *} \\
(0.278)\end{array}$ & -0.151 \\
\hline 12 months & $\begin{array}{l}-0.784^{* * *} \\
(0.174)\end{array}$ & -0.170 & $\begin{array}{l}-0.765^{* * *} \\
(0.143)\end{array}$ & $\begin{array}{l}-0.660^{* * *} \\
0.177\end{array}$ & -0.152 & $\begin{array}{l}-0.869^{* * *} \\
(0.140)\end{array}$ & -0.182 \\
\hline \multicolumn{8}{|c|}{$\begin{array}{l}\text { b. Distance-affected vs. non-affected Belleville jobseekers (Treated } 2 \text { vs. Control 2) } \\
\text { Gross exits }\end{array}$} \\
\hline 6 months & $\begin{array}{c}-1.055 \\
(1.090)\end{array}$ & -0.124 & $\begin{array}{l}-0.292 \\
(0.670)\end{array}$ & $\begin{array}{l}-0.495 \\
(0.823)\end{array}$ & -0.063 & $\begin{array}{c}-0.591 \\
(0.785)\end{array}$ & -0.072 \\
\hline 12 months & $\begin{array}{c}-0.190 \\
(0.401)\end{array}$ & -0.036 & $\begin{array}{c}0.030 \\
(0.314)\end{array}$ & $\begin{array}{c}0.099 \\
(0.389)\end{array}$ & 0.020 & $\begin{array}{c}-0.119 \\
(0.319)\end{array}$ & -0.023 \\
\hline Durable exits & & & & & & & \\
\hline 6 months & $\begin{array}{c}-0.778 \\
(1.123)\end{array}$ & -0.060 & $\begin{array}{c}-1.411 \\
(1.068)\end{array}$ & $\begin{array}{c}-0.152 \\
(0.322)\end{array}$ & -0.033 & $\begin{array}{c}-0.503 \\
(0.803)\end{array}$ & -0.043 \\
\hline 12 months & $\begin{array}{c}-0.465 \\
(0.431)\end{array}$ & -0.084 & $\begin{array}{c}-0.215 \\
(0.351)\end{array}$ & $\begin{array}{c}-0.146 \\
(0.410)\end{array}$ & -0.029 & $\begin{array}{c}-0.384 \\
(0.363)\end{array}$ & -0.072 \\
\hline $\begin{array}{l}\text { c. Un-activated } \\
\text { Gross exits }\end{array}$ & elleville jobseekers & 5 vs un-activate & d outsiders (Treated 3 vs. & . Control 3) & & & \\
\hline 1 month & $\begin{array}{c}0.105 \\
(0.085)\end{array}$ & 0.022 & $\begin{array}{l}-0.023 \\
(0.085)\end{array}$ & $\begin{array}{l}-0.087 \\
(0.100)\end{array}$ & -0.017 & $\begin{array}{c}0.109 \\
(0.075)\end{array}$ & 0.024 \\
\hline 2 months & $\begin{array}{c}0.052 \\
(0.082)\end{array}$ & 0.012 & $\begin{array}{c}-0.051 \\
(0.081)\end{array}$ & $\begin{array}{l}-0.100 \\
(0.090)\end{array}$ & -0.024 & $\begin{array}{c}0.076 \\
(0.075)\end{array}$ & 0.016 \\
\hline 3 months & $\begin{array}{r}-0.030 \\
(0.105)\end{array}$ & -0.004 & $\begin{array}{r}-0.016 \\
(0.103)\end{array}$ & $\begin{array}{l}-0.140 \\
(0.113)\end{array}$ & -0.021 & $\begin{array}{l}0.073 \\
(0.098)\end{array}$ & 0.009 \\
\hline
\end{tabular}

Interpretation of the table: in 2009, using the parametric estimation strategy, the probability of gross 6-month durable exits from unemployment for female jobseekers belonging to the new Belleville agency (Treated Group 1) was $29.7 \%$ lower than the probability off gross 6-month durable exits from unemployment of the female jobseekers of Control group 1.

Source: FHS-Pôle Emploi, first spell per individual.

Number of observations: 94,650 .

Covariates: gender, diploma ( 3 levels), age, and time since the last unemployment spell, job experience and quarter of entrance in unemployment, and agency fixed effect.

Gross exits: difference of the effect of distance on the probability of exiting unemployment after having been unemployed for 6 and 12 months.

Durable exits: difference of the effect of distance on the probability of not having been unemployed the 6 and 12 months that followed an exit from unemployment.

${ }^{* * *}$ significant at $1 \%,{ }^{* *}$ at $5 \%,{ }^{*}$ at $10 \%$. Standard errors are given in parenthesis below the estimate. The propensity score matching standard errors are obtained by bootstrap with 200 replications.

${ }^{10}$ Only year 2009 was kept in this version of the paper since, again, no significant results were found for years 2010 and 2011 . Results for years 2010 and 2011 are available upon request. 
no major differences neither in the significance of coefficients nor in the magnitude of marginal effects between the estimations presented in Tables 2 and 3. We find that there are no significant differences in the employment outcomes of the distance-affected and distance un-affected jobseekers affiliated to the new Belleville agency (see Table 3b): agency accessibility is not a significant determinant of exiting unemployment for any of the specific groups considered. We also find evidence of adverse transitory organizational effects (negative coefficients and marginal effects of Table 3a), with some differences across the groups. Male jobseekers were more affected by the organizational dysfunction of the newly-minted Belleville's agency than female jobseekers (marginal coefficients range from -0.156 to -0.321 for males vs. from -0.168 to -0.297 for females). Less educated jobseekers were also more penalized by adverse institutional effects than more educated ones (marginal coefficients range from -0.151 to -0.314 for un-educated jobseekers vs. from -0.152 to -0.299 for college-educated ones).

In a second robustness check, we need to make sure that the results found for the year 2009 can be associated to the action of the public employment agency, and are not due to a specific exogenous economic slowdown that asymmetrically affected the Belleville area's labour market. To do so, we compare the employment prospects of the short-term unemployed workers of the Belleville area (Treated group 3) and the shortterm unemployed workers of neighbouring control areas (Control group 3). None of these jobseekers were yet enrolled in an activated labour market public policy, so that any adverse difference in their employment prospects cannot be linked to an agency effect but, rather, reflects asymmetric local economic conditions. Since we find not significant difference between these Treated and Control groups 3 (see Tables 2c and $3 \mathrm{c}$ ), we rule out the hypothesis of a specific Belleville slowdown that would explain the significant coefficients found for 2009: jobseekers who were not subjected to active labour market policies were not affected by either accessibility or organizational agency effects. This suggests that the negative coefficients found for the year 2009 (Tables $2 \mathrm{a}$ and $3 \mathrm{a}$ ) do indeed reflect agency effects.
To summarize, we find that, controlling for individual characteristics of jobseekers and for institutional effects, there is no evidence of a worker/agency spatial mismatch: accessibility to agencies does not determine jobseekers' exits from unemployment. However, echoing the vast empirical literature on the role of local public employment agencies on the employment prospects of jobseekers, we find evidence that agency effects do matter, even if here they take the form of short-term detrimental organizational effects.

\section{Conclusion}

In this paper, we question whether accessibility to local public employment agencies impacts exits from unemployment. To do so, we also take advantage of a quasi-experiment created by a zoning modification in the catchment area of an agency in the French region of Lyon. We find evidence that when controlling for individual characteristics and institutional effects, distance to agencies does not affect the matching process efficiency. Even if this result is localized and specific, is the first that relies on a methodology and data sources that clearly tackle the issue of the potential endogeneity of accessibility to agencies.

In terms of public policy, examining whether distance to agencies affects jobseekers' employment prospects is relevant because it conditions the choice between two alternatives, egalitarian versus Rawlsian policy orientations. In the egalitarian scenario, equal accessibility to the public placement service is guaranteed to all jobseekers by financing a dense network of agencies. In the Rawlsian option, spatial accessibility differentials to agencies are tolerated; however, compensating schemes are put in place for jobseekers with less access to the agencies' network (e.g. payment of transportation costs, extra monitoring through Internet meetings). Our results suggest that accessibility to agencies has little or no effect on the probability of exiting unemployment. An explanation consistent with the spatial mismatch literature could be that travelling to one's agency is compulsory due to the activation of labour market public policies: because activated jobseekers cannot de facto arbitrate between transportation costs and benefits from travel to their agency, distance does not create added friction in the matching process. 
The expensive maintenance of a very dense network of agencies does not appear to be a very efficient public policy, supporting the position of the Cour des Comptes on the re-sizing of the French public employment agency network (Cour des Comptes 2015) which could even have beneficial effects following Launoy and Wälde (2016).

\section{Funding}

This work was supported by the CEPREMAP [Programme 2].

\section{References}

Allard, S. W., and S. Danziger. 2003. "Proximity and Opportunity: How Residence and Race Affect the Employment of Welfare Recipients." Housing Policy Debate 13: 675-700.

Altavilla, C., and F. Caroleo. 2013. "Asymmetric Effects of National-Based Active Labour Market Policies.” Regional Studies 47 (9): 1482-1506.

Bech, L. S. 2015. “The Relationship between Caseworkers and Unemployed Workers." PhD Thesis, School of Business and Social Sciences, Aarhus University.

Becker, S. O., and A. Ichino. 2002. "Estimation of Average Treatment Effects Based on Propensity Scores." Stata Journal 2 (4): 358-377.

Behncke, S., M. Frölich, and M. Lechner. 2010a. "Unemployed and Their Caseworkers: Should They Be Friends or Foes?" Journal of the Royal Statistical Society Series A 173 (1): 67-92.

Behncke, S., M. Frölich, and M. Lechner. 2010b. "A Caseworker like Me. Does the Similarity between the Unemployed and Their Caseworkers Increase Job Placements?” Economic Journal 120 (549): 1430-1459.

Bernardi, V. 2013. "Les sortants des listes de Pôle Emploi en 2011: Stabilisation sur un an du taux de sortie pour reprise d'emploi." DARES Analyses, n²013-04

Bernardi, V., and C. Poujouly. 2011. "Les sortants des listes de demandeurs d'emploi inscrits à pôle emploi, en Mars 2011.” DARES Analyse n²011-071.

Blundell, R., and M. Costa Dias. 2000. "Evaluation Methods for Non-Experimental Data.” Fiscal Studies 21 (4): 427-468.
Blundell, R., M. Costa Dias, M. Costas, and J. Van Reenen. 2004. "Evaluating the Employment Impact of a Mandatory Job Search Program." Journal of the European Economic Association 2 (4): 569-606.

Bunel, M., and E. Tovar. 2015. "Spatial Mismatch Through Local Public Employment Agencies Answers from a French Quasi-Experiment.” TEPP Working Paper $n^{\circ}$ 2015-06, 34 p.

Card, D., J. Kluve, and A. Weber. 2015. "What Works? A Meta Analysis of Recent Active Labor Market Program Evaluations." Ruhr Economic Papers 572.

Cour des Comptes. 2015. Pôle Emploi à l'épreuve du chômage de masse, 176. Paris: Rapport Public Thématique.

Détang-Dessandre, C., and C. Gaigné. 2009. "Unemployment Duration, City Size, and the Tightness of the Labor Market." Regional Science and Urban Economics 39: 266-276.

Dusek, T. 2004. "Spatially aggregated data and variables in empirical analysis and model building for economics. "European Journal of Geography n ${ }^{\circ} 285$. Online document, page last accessed on October 22, 2016. URL: http://cyber geo.revues.org/2654.

Ferracci, M., G. Jolivet, and G. van den Berg. 2014. "Evidence of Treatment Spillovers within Markets." Review of Economics Statistics 96 (5): 812-823.

Fontaine, M., and T. Le Barbanchon. 2012. "Evaluation du suivi mensuel personnalisé mis en place par l'ANPE en 2006." Document d'Études DARES n ${ }^{\circ} 175$, Paris, 48 p.

Frölich, M., and M. Lechner. 2010. "Exploiting Regional Treatment Intensity for the Evaluation of Labor Market Policies." Journal of the American Statistical Association 105 (491): 1014-1029.

Gobillon, L., H. Selod, and Y. Zenou. 2007. "The Mechanisms of Spatial Mismatch." Urban Studies 44 (12): 2401-2427.

Hainmueller, J., B. Hofman, G. Krug, and K. Wolf. 2011. “Do Lower Caseloads Improve the Effectiveness of Active Labor Market Policies? New Evidence from German Employment Offices.” LASER Discussion Paper 2011/52.

Hilal, M. 2010. "ODOMATRIX. Calcul de distances routières intercommunales." Cahier des Techniques de l'INRA 41-63.

Hill, C. J. 2006. "Casework Job Design and Client Outcomes in Welfare-to-work Offices." Journal of Public Administration Research and Theory 16 (2): 263-288 doi:10.1093/jopart/ mui043.

Joassart-Marcelli, P., and A. Giordano. 2006. "Does Local Access to Employment Services Reduce Unemployment? A GIS Analysis of One-Stop Career Centers." Policy Sciences 39 (4): 335-359.

Koning, P. 2009. "The Effectiveness of Public Employment Service Workers in the Netherlands." Empirical Economics 37 (2): 393-409.

Kuhn, P., and H. Mansour. 2014. "Is Internet Job Search Still Ineffective?” The Economic Journal 124 (581): 1213-1233.

Lagerstrom, J. 2011. "How Important and Why are Caseworkers? New Evidence from Swedish Employment Offices." Institute for Labor market Policy Evaluation Working Paper 2011-10. 
Launoy, A., and K. Wälde. 2016. "The Employment Effect of Reforming a Public Employment Agency." European Economic Review 84: 140-164.

Lechner, M., and J. Smith. 2007. "What Is the Value Added by Caseworkers?” Labour Economics 14 (2): 135-151.

Rosholm, M. 2014. "Do Case Workers Help the Unemployed? Evidence for Making a Cheap and Effective Twist to Labor Market Policies for Unemployed Workers.” IZA World of Labor 2014/72.

Rubin, D. B. 1977. "Assignment to Treatment Group on the Basis of a Covariate." Journal of Educational Statistics 2: 1-26.

Suárez Cano, P., M. Mayor Fernández, and B. Cueto Iglesias. 2012a. "How Important Is Access to Employment Offices in
Spain? an Urban and Non-Urban Perspective." Investigaciones Regionales 21: 119-140.

Suárez Cano, P., M. Mayor Fernández, and B. Cueto Iglesias. 2012b. "The Accessibility to Employment Offices in the Spanish Labour Market." Papers in Regional Science 91 (4): 823-848.

Suárez Cano, P., B. Cueto Iglesias, M. Mayor Fernández and M. Henar Salas-Olmedo. 2015. "People- and PlaceSensitive Perspective for Studying the Potential for the Role of Job Centers. "SSRN Working Paper n²554128. Wathen, M.V., and S.W. Allard. 2014. "Local Nonprofit Welfare Provision: the United States and Russia." Public Administration Issues, Special Issue: 7-28. 